\title{
FAKTOR YANG MEMPENGARUHI DERAJAT KESEHATAN MENURUT HL BLUM
}

\author{
Andi Wulan Purnamasari.A \\ (70200121101) \\ Jurusan Kesehatan Masyarakat \\ Universitas Islam Negeri Alauddin Makassar
}

\begin{abstract}
The degree of public health is a measure of the welfare and quality of human resources using key quality indicators such as mortality, morbidity, birth rates, community nutritional status, and others. The survey was conducted using $\mathrm{HL}$ Blum theory analysis where the degree of public / individual health is influenced by the environment, lifestyle, genetics, and health services.
\end{abstract}

\section{Abstrak}

Derajat kesehatan masyarakat merupakan salah satu ukuran kesejahteraan dan kualitas sumber daya manusia yang menggunakan indicator kualitas utama seperti angka kematian, angka kesakitan, angka kelahiran, status gizi masyarakat, dan lainlain. Survey dilakukan dengan menggunakan analisis teori H.L Blum dimana derajat kesehatan masyarakat/perorangan dipengaruhi oleh lingkungan, gaya hidup, genetic, dan pelayanan kesehatan. (Mutika Wati, 2020)

Pendahuluan

Pembangunan kesehatan merupakan bagian integral dari pembangunan nasional. Dalam konstitusi Organisasi Kesehatan Dunia tahun 1948 disepakati antara lain bahwa diperolehnya derajat kesehatan yang setinggi-tingginya adalah hak yang fundamental bagi setiap orang tanpa membedakan ras, agama, politik yang dianut dan tingkat sosial ekonominya. Program pembangunan kesehatan yang dilaksanakan telah berhasil meningkatkan derajat kesehatan masyarakat secara cukup bermakna, walaupun masih dijumpai berbagai masalah dan hambatan yang akan mempengaruhi pelaksanaan pembangunan kesehatan. Di samping itu, reformasi kesehatan diperlukan mengingat lima fenomena utama yang berpengaruh terhadap pembangunan kesehatan. Pertama, perubahan-perubahan pada dinamika kependudukan yang mendorong lahirnya transisi demografi dan epidemiologi. Kedua, temuan-temuan ilmu dan teknologi (Iptek) kedokteran yang membuka wawasan baru. Ketiga, tantangan global sebagai akibat kebijakan perdagangan bebas, revolusi informasi, telekomunikasi dan transportasi. Keempat, perubahan lingkungan yang berpengaruh terhadap derajat dan upaya kesehatan. Kelima, demokratisasi, yang menuntut pemberdayaan dan kemitraan. (Sukowati \& Shinta, 2003) 


\section{Tinjauan Pustaka}

\section{A. Biografi Singkat HL Blum}

Dr. Hendrik L. Blum atau yang lebih di kenal dengan nama HL Blum adalah seorang professor emeritus administrasi kesehatann dan perencanaan di University of California, Berkeley, dan pelopor dalam reformasi perawatan kesehatan. Hendrik L. Blum lahir pada 11 November 1915, di San Fransisco. Dibesarkan di sebuah daerah pertanian di distrik Napa. Perhatian yang tulus oleh rekan-rekannya selama mengalami kesusahan menjadikan HL Blum tumbuh dan memiliki tingkat sensivitas dan perhatian yang tinggi untuk individu tidak mendapat pelayanan dari lembagalembaga sosial. Pada tahun 1937, HL Blum memperoleh gelar sarjana kimia dari UC Berkeley. Dan pada masa studinya di universitas tersebut dia bertemu dengan yang juga seorang mahasiswi di UC Berkeley, Mariam H. Ehrich, yang mengambil studi kesejahteraan sosial. Mereka menikah pada tahun 1939 malam natal dan tetap bersama sampai kematiannya pada 21 oktober 2005. (Azzahra, 2012)

\section{B. Pengertian dari 4 Faktor Yang Mempengaruhi Derajat Kesehatan}

\section{Keturunan}

Keturunan merupakan hubungan darah antara satu individu ke individu baru. Keturunan merupkan individu baru dari generasi sebelumnya yang bertujuan untuk meneruskan generasi selanjutnya. Keturunan merupakan lahirnya makhluk hidup baru.

\section{Lingkungan}

Lingkungan adalah segala sesuatu yang ada di sekitar manusia dan mempengaruhi perkembangan kehidupan manusia. Adapun pengertian lain, lingkungan adalah kombinasi antara kondisi fisik yang mencakup keadaan sumber daya alam seperti tanah, air, energy surya, mineral, serta flora dan fauna yang tumbuh di atas tanah maupun di dalam lautan, dengan kelembagaan yang meliputi ciptaan manusia seperti keputusan bagaimana menggunakan lingkungan fisik tersebut.

\section{Perilaku}

Perilaku adalah serangkaian tindakan yang dibuat oleh individu, organisme, system, atau entitas buatan dalam hubungannya dengan dirinya sendiri atau lingkungannya, yang mencakup system atau organism lain di sekitarnya serta lingkungan fisik.

\section{Yankes}

Perawatan kesehatan atau pelayanan kesehatan (Yankes) adalah pemeliharaan atau peningkatan status keesehatan melalui usaha-usaha pencegahan, diagnosis, terapi, pemulihan, atau penyembuhan penyakit, cedera, serta gangguan fisik dan mental lainnya. 
C. Ada 4 Faktor Yang Mempengaruhi Derajat Kesehatan Menurut HL Blum dan Beberapa Contohnya

\section{Keturunan (Heredity)}

Faktor keturunan/genetic ini sangat berpengaruh pada derajat kesehatan. Hal ini karena ada beberapa penyakit yang diturunkan lewat genetic atau factor yang telah ada pada diri manusia yang dibawa sejak lahir, misalnya : dari golongan penyakit keturunan, diantaranya: diabetes mellitus, asma bronkia, epilepsy, retardasi mental, hipertensi, dan buta warna. Factor keturunan ini sulit untuk di intervensi dikarenakan hal ini merupakan bawaan dari lahir dan jika di intervensi maka harga yang dibayar cukup mahal. Berikut contoh factor keturunan dapat mempengaruhi kesehatan:

a. Perkawinan antar golongan darah tertentu akan mengakibatkan leukemia.

b. Adanya kretinisme yang diakibatkan mutasi genetic.

\section{Lingkungan (Environment)}

Lingkungan ini meliputi lingkungan fisik (baik natural atau buatan manusia) misalnya sampah, air, udara, dan perumahan, dan sosiokultur (ekonomi, pendidikan, pekerjaan dan lain-lain). Pada lingkungan fisik, kesehatan akan dipengaruhi oleh kualitas sanitasi lingkungan dimana manusia itu berada. Hal ini dikarenakan banyak penyakit yang bersumber dari buruknya kualitas sanitasi lingkungan, misalnya : ketersediaan air bersih pada suatu daerah akan mempengaruhi derajat kesehatan karena air merupakan kebutuhan pokok manusia dan manusia selalu berinteraksi dengan air dalam kehidupan sehari-hari. Sedangkan lingkungan sosial berkaitan dengan kondisi perekonomian suatu masyarakat. Semakin miskin individu/masyarakat maka akses untuk mendapatkan derajat kesehatan yang baik maka akan semakin sulit.

Misalnya manusia membutuhkan makanan dengan gizi seimbang untuk menjaga kelangsungan hidup, jika individu/masyarakat berada pada garis kemiskinan maka akan sulit untuk memenuhi kebutuhan makanan dengan gizi seimbang. Demikian juga dengan tingkat pendidikan individu/masyarakat, semakin tinggi tingkat pendidikan individu/masyarakat maka pengetahuan untuk hidup sehat akan semakin baik. Beberapa contoh factor lingkungan yang dapat mempengaruhi kesehatan masyarakat antara lain :

a. Adanya sanitasi lingkungan yang baik akan meningkatkan derajat kesehatan masyarakat.

b. Ada norma agama pada umat islam tentang konsep haram terhadap alcohol akan menurunkan tingkat konsumsi alcohol.

c. Dan semakin tinggi tingkat pendidikan individu maupun masyarakat maka pengetahuan akan cara hidup sehat semakin baik. 


\section{Perilaku (Life styles)}

Gaya hidup individu atau masyarakat merupakan factor kedua mempengaruhi derajat kesehatan masyarakat karena sehat dan tidak sehatnya lingkungan kesehatan individu, keluarga dan masyarakat sangat tergantung pada perilaku manusia itu sendiri, di samping itu juga dipengaruhi oleh kebiasaan, adat istiadat, kepercayaan, pendidikan, sosial ekonomi, dan perilaku-perilaku lain yang melekat pada dirinya. Contohnya : dalam masyarakat yang mengalami transisi dari masyarakat tradisional menuju masyarakat modern, akan terjadi perubahan gaya hidup pada masyarakat tersebut yang akan mempengaruhi derajat kesehatan.

Misalnya : pada masyarakat tradisional dimana sarana transportasi masih sangat minim maka masyarakat terbiasa berjalan kaki dalam beraktivitas, sehingga individu/masyarakat senantiasa menggerakkan anggota tubuhnya (berolahraga). Pada masyarakat modern di mana saran transportasi sudah semakin maju, maka individu/masyarakat terbiasa beraktivitas dengan menggunakan transportasi seperti kendaraan bermotor sehingga individu/masyarakat kurang menggerakkan anggota tubuhnya (berolahraga). Kondisi ini dapat beresiko mengakibatkan obesitas pada masyarakat modern karena kurang berolahraga ditambah lagi kebiasaan masyarakat modern mengkonsumsi makanan cepat saji yang kurang mengandung serat. Fakta tersebut akan mengakibatkan transisi epidemiologis dari penyakit menular ke penyakit degenerative. Berikut contoh dari life style yang dapat mempengaruhi kesehatan seseorang:

a. Perilaku perokok sejak dini akan meningkatkan risiko kanker pada paru-paru.

b. Perilaku mengkonsumsi makanan cepat saji (junk food) akan meningkatkan risiko obesitas yang beresiko pada penyakit jantung.

c. Kebiasaan melakukan konsep $3 \mathrm{M}$ (menguras, mengubur, dan menutup) pada pencegahan DBD akan menurunkan prevalensi penyakit DBD.

\section{Yankes atau pelayanan kesehatan (Health Care Services)}

Pelayanan kesehatan merupakan factor ketiga yang mempengaruhi derajat kesehatan masyarakat, karena keberadaan fasilitas kesehatan sangat menentukan dalam pelayanan pemulihan kesehatan, pencegahan terhadap penyakit, pengobatan dan keperawatan serta kelompok dan masyarakat yang memerlukan pelayanan kesehatan. Ketersediaan fasilitas sangat berpengaruh oleh lokasi, apakah dapat dijangkau oleh masyarakat atau tidak, tenaga kesehatan yang memberikan pelayanan, informasi dan motivasi masyarakat untuk mendatangi fasilitas dalam memperoleh pelayanan, serta program pelayanan kesehatan itu sendiri. Semakin mudah akses individu atau masyarakat terhadap pelayanan kesehatan maka derajat kesehatan masyarakat semakin baik. Adapun contoh factor pelayanan kesehatan yang dapat mempengaruhi kesehatan, dapat terlihat sebagai berikut : 
a. Adanya upaya promotif terhadap penularan HIV/AIDS akan menurunkan prevalensi HIV/AIDS.

b. Tersedianya sarana dan prasarana kesehatan yang baik akan memudahkan masyarakat dalam mendapatkan pelayanan kesehatan yang bermutu dan berkualitas.

c. Adanya asuransi kesehatan akan memudahkan individu/masyarakat untuk mengakses pelayanan kesehatan. (Eliana,S.K.M., M.P.H \& Sumiati,S.Pd., M.Kes, 2020) 


\section{DAFTAR PUSTAKA}

Azzahra, N. (2012, April 21). Realitas Kesehatan [Pengetahuan]. jurnalkesehatanmasyarakat. blogspot.com.

Eliana,S.K.M., M.P.H, \& Sumiati,S.Pd., M.Kes, S. (2020, April 3). Konsep Kesehatan Masyarakat [Kesehatan]. Pediailmu.com.

Mutika Wati, M. D. (2020). Gambaran Perilaku Hidup Sehat Masyarakat pada 2018. 18(Promosi Kesehatan dan IImu Perilaku), 16-22. https://doi.org/10.35882/jpk.v18i2.5

Sukowati, S., \& Shinta, S. (2003). Peran Tenaga Kesehatan Masyarakat Dalam Mengubah Perilaku Masyarakat Menuju Hidup Bersih Dan Sehat. 13(Peran tenaga kesehatan dalam perilaku hidup bersih dan sehat), 31-32. 